\title{
Trade Liberalization and Employment Effects in Ukraine
}

\author{
Atanas Christev \\ Department of Economics and CERT, Heriot-Watt University, Edinburgh; and IZA \\ Bonn \\ Olga Kupets \\ Department of Economics, National University-Kiev Mohyla Academy, Ukraine; and \\ IZA, Bonn

\section{Hartmut Lehmann} \\ Department of Economics, University of Bologna; IZA Bonn; CERT, Heriot-Watt \\ University, Edinburgh; and Labor Group, EROC, Kiev School of Economics
}

First Draft: June 2003

This Version: October 2005

\footnotetext{
We would like to thank John Haltiwanger and Peter Wright and the participants at the GEP Conference, Nottingham, June 2003, and the IZA-Upjohn-WDI conference on "Microeconomic Aspects of Labor Reallocation", Kalamazoo, Michigan, August 2003, for valuable comments and insightful discussions. This paper is partially financed by the CERT-RWI project "Analysis of Labor Markets in Transition Countries Using Large Micro Data Sets." Kupets is grateful to the "INTAS" program for facilitating her stay in Edinburgh, during which this first version of the paper took shape.
} 


\begin{abstract}
This paper addresses the important issue of the effects of trade liberalization on labor market job flows. It studies the case of Ukraine where we view the sudden openness of the economy to trade as a quasi-natural experiment. We use disaggregated data on manufacturing industries and customs data on trade flows taking account of shifting trade patterns after the disintegration of CMEA trade regime. We provide some first evidence that 3-digit NACE sector job flows are predominantly driven by idiosyncratic factors within industries. Other things equal, there is increased labor shedding as larger non-state share in industry relates to less job creation and more job destruction. Trade openness does affect job flows in Ukrainian manufacturing disproportionately according to trade orientation. We find that while trade with CIS decreases job destruction, trade with the EU increases excess reallocation mainly through job creation.
\end{abstract}

JEL Classification Numbers: E24, F14, J63, P23.

Key Words: Job Creation; Job Destruction; Ukraine; Trade Flows and Trade Liberalization 


\section{Introduction}

The flexibility of labor markets is an important feature of well-functioning market economies. Davis and Haltiwanger $(1999,1992)$ and Baldwin, Dunne and Haltiwanger (1998) report that in the U.S. and in Canada roughly one in every ten jobs is created and one in every ten jobs is destroyed each year. Flexibility of the labor market is important because it permits the rapid reallocation of resources to the most efficient uses and thus it may be vital for economic growth. Labor reallocation is to a large extent driven by job creation and job destruction. Businesses react continuously to shocks by changing output and input levels at a high pace leading to substantial destruction and creation of jobs at high frequencies. Job creation and job destruction are thus intimately linked to productivity growth. Firms (sectors) that engage in restructuring destroy low productivity jobs and create high productivity ones, leading to large job turnover, an increase in labor productivity and better general performance.

A high degree of job reallocation, while beneficial for an economy as a whole, can, however, have large negative effects for those workers who are displaced from their jobs. There is ample evidence, in particular from Anglo-Saxon labor markets, that the average displaced worker faces prolonged non-employment spells and longterm earnings losses (see e.g. Kuhn (2002) and Jacobson, Lalonde and Sullivan (1993)).

Labor reallocation, brought on by the reallocation of jobs across firms and sectors, is an especially pertinent issue in transition economies. The reallocation of labor from inefficient firms (usually non-restructured state and privatized firms) to efficient ones (usually new private and restructured state and privatized firms) increases overall 
labor productivity and enhances efficiency during the transition from plan to market (Blanchard (1997)). How job creation and destruction have contributed to this reallocation process across businesses and sectors has been the subject of a growing literature on job gross flows in Central Europe and the CIS, which is summarized in Haltiwanger, Lehmann and Terrell (2003). Like in mature capitalist economies, the welfare gains generated by the ongoing process of labor reallocation are, however, not distributed evenly. Many low-skilled and older workers who are displaced from their jobs incur large costs above all in the form of long spells of non-employment, as Lehmann, Philips and Wadsworth (2005) and Lehmann, Pignatti and Wadsworth (2005) have shown for Estonia and Ukraine where data on displacement are available.

Beneficial and detrimental outcomes of labor reallocation induced by changing trade patterns have been widely discussed in the literature on the impact of globalization on Western domestic labor markets. However, there are only a few papers that look at how trade affects job creation and job destruction directly. While Klein, Schuh and Triest (2003) estimate the effects of real exchange rates on job creation and job destruction for the US manufacturing industry, Lewinsohn (1999) investigates the influence of trade liberalization on job creation and destruction in Chile.

With respect to the impact of shifting trade patterns on domestic labor markets, transition economies provide something of a quasi-natural experiment. Under central planning the state had a foreign trade monopoly. Firms were not in principle acting autonomously in export markets. At the same time, enterprises were sheltered from import competition. Firms in most centrally planned economies were completely 
isolated from world markets. ${ }^{1}$ With the start of transition the foreign trade state monopoly was abolished and trade was liberalized. As a consequence of trade liberalization, we see a strong re-orientation of trade away from the defunct CMEA trade area to Western markets, in particular to the EU. In addition, trade liberalization implies that many firms engage autonomously in fast growing Western export markets. The same firms or other firms have to deal themselves with import competition. Firms' engagement in export markets and the abrupt exposure to import competition imply that some sectors of industry in transition countries open up to the world economy over a short time horizon at a very rapid pace. Industrial sectors in mature capitalist economies have opened up much more gradually over the eighties and nineties, making it difficult to isolate the effect of changing trade patterns on employment adjustment in domestic labor markets.

We try to take advantage of the rapid opening up of one transition country, Ukraine. As we shall show in the next section, Ukrainian trade flows to and from areas outside the Commonwealth of Independent States (CIS) have increased dramatically over the last decade. We exploit this dramatic increase and investigate whether and how trade liberalization causally affects job creation and destruction in three-digit industrial sectors. The sectoral gross job flows are based on establishmentlevel data from the Ukrainian registry data for the years 1993-2000. In an earlier study, two of the authors used Ukrainian establishment level data from the Amadeus data base to look at the impact of trade liberalization on job gross flows at the establishment level in the late nineties (Konings, Kupets and Lehmann (2003)). The

\footnotetext{
${ }^{1}$ In Poland and Hungary, economic reforms of the central planning system gave some autonomy to state-owned enterprises in the eighties. Some of the Hungarian and Polish enterprises did have trade relationships with Western firms already in the eighties as a consequence of these reforms (see e.g. Repkine and Walsh (1999) who study Polish enterprises). In the Soviet Union, on the other hand, where the Classical Planning System was less affected by economic reform throughout the Communist
} 
present paper is complementary insofar as it extends the analysis to the sectoral level and augments the time dimension to nearly the entire last decade. With data that have a substantial time series dimension we hope to better control for cyclical and idiosyncratic shocks. Using a generalized method of moments (GMM) estimator we thus might be able to better isolate the effect of trade liberalization on gross job flows.

The following section gives a short account of the developments of the industrial sector in Ukraine over the nineties and looks at the evolution of trade flows over the same period. In the subsequent section we describe our data sources, briefly review the job flow measures that we employ in the analysis and sketch the construction of indices of trade openness at the sector level. This is followed by a discussion of the raw correlations of the trends of job flows and of trade orientation of sectors. Section four develops the estimation framework and reports results from our GMM estimations. The final section offers some conclusions.

\section{Ukrainian Industry and Trade in the Nineties}

Reform efforts to transform the Ukrainian economy have been either nonexistent or very inconsistent in the nineties of the last century, which is the analyzed period in this paper. The capture of the state by a few oligarchic groups, the exclusion of the majority of the population from the decision making process and weak property rights resulted in stagnancy, corruption and a collapse in output for most of the decade (Aslund, 2002). In the first half of the nineties runaway inflation, bordering for a prolonged period on hyperinflation, was one of the manifestations of the poor economic policies that brought Ukraine on the brink of collapse. Only towards the

regime, the foreign trade monopoly of the state was not touched until the implosion of the centrally planned economy. 
end of the nineties were serious reforms undertaken that loosened the grip of the oligarchs and that spurned robust and unabated growth for the first time since the collapse of the Soviet Union.

Figure 1, which shows the trends of production and employment, makes the point quite forcefully that the nineties were a lost decade for Ukraine. After an extremely sharp contraction of industrial output in 1993 (the year of the hyperinflation) we see a five-year trough until some recovery in 1999 and 2000 occurs. By the end of the decade industrial output had "recovered" to only about $60 \%$ of the pre-transition level, which points to a dismal performance in comparison with all those Central and East European transition countries that have not been affected by armed conflict.

It is also striking that employment shows a steady decline hinting at substantial labor shedding throughout the period. This labor shedding was driven by large job destruction as Table 1 makes clear. Throughout the decade we see job destruction rates at levels that are observed in Western economies with rather flexible labor markets (Davis and Haltiwanger (1999)), while job creation rates are small in international perspective. What is interesting, though, is that job creation does take place at all during this period and that it does gather pace in 1999 and 2000 when industrial output grows. Despite the enormous fall in industrial output and the cumulative employment contraction of roughly $40 \%$, jobs are continuously reallocated at an increasing pace as the secular rise of the excess job reallocation demonstrates.

How much trade contributes to this reallocation is the focus of the paper. A first cursory look at Ukrainian trade flows (Figures 2 and 3) yields two striking facts. First, the above-mentioned re-orientation from CIS to Western economies that one 
generally observes for transition countries is clearly revealed by the shifting trade patterns in Ukraine. Both exports and imports are re-directed away from the CIS to the EU and the rest of the world (ROW represents all those areas that are not in the EU and in the CIS). Second, we see a spectacular rise of EU and ROW trade flows throughout the decade, while CIS trade flows decline in the second half of the nineties. This large increase in trade flows will be exploited in the analysis that follows.

\section{The Data}

The empirical analysis is based on industry-level data for a panel of 95 threedigit NACE mining and manufacturing industries in Ukraine over the 1994-2000 period, containing information from three diverse sources. The panel is restricted to the subset of Ukrainian industries for which data on job and trade flows are available over the whole period. In unreported results, we have used bootstrap techniques to perform tests of the null hypothesis that gross job flows of all firms (including entry and exit) and gross job flows of continuous firms are determined by the same data generation process. In all cases over the sample period, we were not able to reject the null hypothesis, which implies that entry and exit do not influence our results.

Annual sectoral data on job creation, destruction and reallocation are constructed from the establishment-level registry data set from 1993 to 2000 provided by the State Statistical Committee of Ukraine ("Derzhkomstat"). ${ }^{2}$ Although the initial registry data also cover establishments from some non-industrial sectors $(4.84 \%$ of the initial sample), we restrict our analysis of job flows to firms in mining, manufacturing 
industries and electricity, gas and water supply (i.e. to 3-digit NACE sectors from 101 to 410$).^{3}$ The manufacturing sample covers about $80 \%$ of officially reported total industrial employment. The data set that we use in the analysis comprises only firms that we can identify with certainty as continuing firms, i.e. firms that have positive employment at least for the two adjacent years. Information on ownership is based on the ownership codes of the enterprises in the registries and is available only for $2000 .^{4}$ Annual data on import and export flows come from the Ukrainian Customs Office data on import and export volumes in US dollars by countries of origin and destination disaggregated by the six-digit commodity groups according to the Harmonized Commodity Description and Coding System (HS). ${ }^{5}$

Since we attempt to compare and contrast the role played by trade with the EU countries from that of trade with the CIS countries in altering employment in Ukrainian manufacturing, we focus our analysis on the data set consisting of export and import volumes in three trading areas: CIS countries, EU countries and the rest of the world $(\mathrm{ROW})$. We construct the following index of openness: $\left(\operatorname{Exp}_{\mathrm{it}}+\mathrm{Imp}_{\mathrm{it}}\right)$ / $\left(\operatorname{Exp}_{i t}+\operatorname{Imp}_{i t}+\operatorname{Prod}_{i t}\right)$, which uses exports, imports and production of sector $\mathrm{i}$ in order to calculate the share of trade in total turnover. For each industry, this index is then applied to the three trading areas, resulting in the three trade area-specific indices of openness shown in Appendix 1. It is worth pointing out that these unique measures of

\footnotetext{
${ }^{2}$ Since the Derzkkomstat used the old classification of industries OKONKh (Classification of branches of national economy) till 2001 we converted 5-digit OKONKh industries to the 3-digit NACE sectors for our further analysis at the sectoral level.

${ }^{3}$ We also eliminated sectors 205 (Manufacture of other products of wood), 233 (Processing of nuclear fuel) and 372 (Recycling of non-metal waste) because there is insufficient number of observations for sectoral analysis. All prison-based enterprises (about 170 establishments) were excluded from the sample.

${ }^{4}$ For the moment, we can distinguish only between state and non-state (including collective, private and foreign) ownership

${ }^{5}$ HS codes were also converted to the 3-digit NACE sectors. In our study we exclude sectors 296 (Manufacture of weapons and ammunition) and 362 (Manufacture of jewellery) because of nonavailability of trade flows data for the whole interval from 1993 to 2000, and then we base our analysis only on sectors used in the manufacturing sample of the Derzhkomstat data set
} 
trade openness to three distinct trading areas allow us to use counterfactuals in our analysis since some industries remained closed to the shifting trading patterns before and even after the reform, while others increased their trade disproportionately in world markets.

The three panels of Figure 4 depict the percentile distribution of the openness indices over the sample period. What is evident is the large increase in trade openness over a relatively short period of time in many Ukrainian industrial sectors. The median $\left(50^{\text {th }}\right.$ percentile $)$ value of the index rises from almost 1 percent in the beginning of the period to more than 20 percent at the end of 2000 . It is also striking that a large number of closed sectors stayed closed over the same years, as shown by the $10^{\text {th }}$ and $25^{\text {th }}$ percentile of the distribution. Panel B, in addition, shows that this increase occurred differently and more unevenly for trade oriented towards CIS countries.

Following Davis and Haltiwanger (1992, 1999) gross job creation (pos) is defined as the sum of all employment gains in all expanding firms, while gross job destruction (neg) is the sum of all employment losses in all contracting firms in an economy or sector. Usually gross job destruction is expressed as a positive number. These gross job flows can be transformed into rates by dividing them by the total amount of jobs available in an economy or sector. The sum of the gross job creation rate and the gross job destruction rate is the gross job reallocation rate (gross), while the difference is the net aggregate employment growth rate (net) that can be observed in aggregate statistics. A measure of churning or reallocation of jobs which is over and above the amount of job reallocation necessary to accommodate a given net aggregate employment growth rate is the excess job reallocation rate (excess) and is defined as the gross job reallocation rate minus the modulus of the net aggregate 
employment growth rate. We interpret excess as a measure of genuine labor reallocation within a sector.

Job destruction dominates sectoral job flows throughout the sample period as we slice the data by trade openness. Figure 5 shows a dominant job destruction rate for the lowest and highest quartiles of trade orientation with regard to all three trading areas. However, in the latter part of the nineties job creation is rising and job destruction stagnant or falling leading to a larger excess job reallocation rate across the openness distribution. So, genuine labor reallocation within sectors is rising towards the end of the decade no matter how open a sector is towards the respective trading area. These presented raw data thus imply that labor reallocation might be predominantly driven by idiosyncratic factors and not by trade liberalization.

Job destruction is, however, quite different across trade regimes. It is more volatile and has a lower level in the more closed sectors across all three panels. So, more trade openness seems to be correlated with more persistent and larger job destruction, resulting in unabated large labor shedding throughout the sample period. On the other hand, we see a marked downward trend in the job destruction rate and a rising job creation rate in those sectors that are relatively closed. So, labor shedding declines disproportionately in these sectors.

\section{Theoretical Framework and Empirical Specification}

There is little theoretical and empirical work relating gross job flows and international trade (Klein, et. al., 2003a,b). In addition, Haltiwanger, et. al. (1996) establish "no systematic relationship" between job flows and openness to trade in US manufacturing for 1973 to 1986 . To study the employment effects of exposure to 
international trade in the Ukrainian industrial sectors, we closely follow Klein, et. al. (2003a) who study the costly adjustment to trade flows using detailed data on US manufacturing for the period 1973-1993. We specify job flows as a function of trade flows that vary systematically by industry and control for other industry-specific effects (including privatization) and explicitly model dynamic adjustment of labor reallocation in sectors by including lagged dependent variables. Earlier work has shown that adjustment costs in transition tend to differ in non-trivial ways according to industry and ownership. We expect that opening of essentially closed (former CMEA) markets to international trade will affect different industries disproportionately.

Thus, we study the effects of trade liberalization on job creation, destruction, and labor reallocation by analyzing differences in international exposure of industrial sectors in Ukraine controlling for idiosyncratic shocks and ownership structure at the end of period. We construct three different measures of trade openness towards three different groups of countries (EU, CIS (former Soviet Union countries) and the rest of the world (ROW)). In addition, we interact these indexes with a trade weighted (multilateral) real exchange rate to isolate the effects of relative prices and productivity differences according to industrial sectors at 3-digit level. See Appendix 2 for definition of these and other variables used in our estimation.

We estimate these specifications using generalized method of moments (GMM) estimator to account for potential endogeneity problems. The resulting general specification is ${ }^{6}$ :

$$
J F_{i t}=\alpha_{0}+\alpha_{1} J C_{i t-1}+\alpha_{2} J D_{i t-1}+\alpha_{3} O I_{i t}+\alpha_{4} O I_{i t-1}+\alpha_{5} E_{i t}+\alpha_{6} E_{i t-1}+\alpha_{7} D_{i}+\varepsilon_{i t}
$$

\footnotetext{
${ }^{6} \mathrm{We}$ determine the lag structure empirically with a general-to-specific approach to establish a more parsimonious representation of the data. Initially, we used two lags on all variables. We also estimated
} 
This equation is motivated by the model presented in Klein, et. al.(2003), where $\mathrm{JF}_{\text {it }}$ is the job flow rates in 3-digit NACE industry $i$ at time $t$. These include job creation, destruction, net employment growth and excess reallocation rate. $\mathrm{OI}_{\mathrm{it}}$ is defined as the trade openness variable (see Appendix 2) and $E_{i t}$ is the industry-specific real exchange rate. $D_{i}$ captures the effect of privatization and ownership at the end of period. We also include other industry-specific variables such as the coefficient of variation of real wages that affect job reallocation rates and time dummies to account for aggregate shocks.

In addition, we have specified Equation (1) to include the export share and import penetration ratio in industry, and have allowed for the exchange rate to enter both with and without the openness index interaction. Since we expect that the changes in the exchange rate might have a direct influence on job creation and destruction (see Klein, et. al., 2003a), we have also accounted for the growth rate of the multilateral industry-specific real exchange rate in our specification. These alternative specifications are not reported in the tables because they provide little difference to the results below.

The panel structure (95 three-digit level industries over 6 years) of our sample allows us to study the dynamics of partial adjustment in the transition period as well as differing exposure to trade openness, with the inclusion of a lagged dependent variable among the other regressors in the model. It is well accepted that in estimating these dynamic models with relatively large cross-sections over a short time period, 1994-2000, the fixed effects model yields inconsistent estimates. Thus, as pointed out in Equation (1) above, we specify an error components model (random effects) with $\varepsilon_{\mathrm{it}}=\lambda_{\mathrm{t}}+\eta_{\mathrm{i}}+v_{\mathrm{it}}$. This, however, raises well-known additional problems

(1) with the growth rate of the real exchange rate rather than the level, and found no significant 
when lagged dependent variables are included in the model. Thus, we resort to the use of the generalized method of moments (GMM) estimation which has dominated recent studies of dynamic panel regressions. ${ }^{7}$

In estimation we apply the asymptotically efficient (one-step) GMM advocated by Arellano and Bover (1995) and Blundell and Bond (1998). This estimator usually exploits a different number of instruments in each time period. We transform the data and allow lagged endogenous or predetermined variables to enter as instruments in the transformed equations. By construction, the transformed error term does not contain $\eta_{i}$ and orthogonality among the errors is preserved. The original errors may be heteroskedastic but may not be autocorrelated, for which we test formally below, and we treat all variables in our models as potentially endogenous. In addition, we check for serial correlation in the errors to establish consistency. Diagnostics, reported in Tables 5 and 6 , show that neither the robust Sargan nor MA(1) and MA(2) tests provides evidence to suggest that the assumption of serially uncorrelated errors (second-order) is impractical. The choice of the instruments used also appears to be appropriate. ${ }^{8}$ These are reported in the diagnostics section of Tables 5 and 6 to whose main findings we now proceed.

\section{Main Hypotheses and Results}

Changes in trading patterns have a direct effect on the labor demand in different industries and are thus closely related to the pace of job creation and

\footnotetext{
differences.

${ }^{7}$ For background and a detailed discussion see Baltagi (1995, Ch.8). For an overview, see Bond (2002) and Hall (2003).
} 
destruction. Trade theory provides little explanation as to the links, causes and effects of adjustment costs associated with job and worker reallocation. As discussed earlier, previous work has generally focused on the effects of trade on net employment change and neglected other aspects of this process, namely gross job creation and destruction (Gourinchas, 1999 and Klein, et. al. 2003a).

We expect that job destruction will be both more volatile and larger than job creation following trade liberalization in Ukraine. Job destruction caused by increased trade flows may exacerbate unemployment if workers do not reallocate to new jobs or exit the labor force (Lehmann, et al., 2005). Job creation, on the other hand, may be constrained by the lower competitiveness of Ukrainian industries, and especially those industries that are initially either closed to trade with the EU or ROW or that have maintained strong trading ties to former CMEA area (CIS) countries. Open trade policies and flexible exchange rates increase excess job reallocation and stimulate growth as shown by Gourinchas (1999) and Greenway, et. al. (2002). The latter authors point also to the importance of the existence of a credible counterfactual in evaluating the effects of trade liberalization on growth. In the sample period we observe such counterfactuals since while some industries rapidly opened up to trade as transition progresses, others remained closed throughout the period (Figure 4). In addition, we expect that job flows are affected differently by the dispersion of trade openness across industries and trading areas. Higher openness towards the EU, for example, is more likely to increase job creation and decrease job destruction, which is dominant in the initial stage of transition, and thus affects excess job reallocation. Real appreciation of the exchange rate may increase job destruction and decrease job creation. Finally, we anticipate that the privatization processes and ownership

\footnotetext{
${ }^{8}$ Where possible, in addition to predetermined variables, we use the lagged differences and levels of
} 
structure in industries with different trade exposure will influence job creation and job destruction propitiously.

While we consider trade liberalization in its various realizations an important determinant of job reallocation, we anticipate that industry-specific shocks will dominate the determination of gross job flows in the studied period. Our first results confirm this as the four sectoral job flow measures appear to be mainly driven by the lagged values of job creation and destruction. Net employment growth is consistently dominated by job destruction, while excess job reallocation is propelled by job creation. This finding indicates that idiosyncratic factors within industries explain most of the variation of costly employment adjustment in the Ukrainian manufacturing sectors which is in line with the evidence found in Davis, et. al. (1996). In addition, ownership structure seems to be strongly correlated with job flows, as revealed by the significant and large coefficients on the variable PRIV SHARE in both Tables 5 and 6. A larger private share in an industry is associated with less job creation and more job destruction resulting in an increased labor shedding. There is also weak evidence that an industry with a larger private share exhibits less excess job reallocation. In our interpretation of the coefficients on PRIV SHARE we are careful not to suggest a causal effect of ownership structure of industries on employment adjustment since the variable we have constructed PRIV SHARE does not capture the evolving ownership distribution in industrial sectors over time. It is instead an endof-period variable controlling for the cumulative ownership changes that have occurred in the industrial sectors in Ukraine over the intervening years.

Does trade liberalization affect sectoral job flows in Ukrainian manufacturing? In Table 5, we report a significant positive coefficient on the lagged openness index 
for EU trade in the job creation and excess job reallocation regressions. This asserts that as industries become more exposed to trade and competition in EU markets over time, they reallocate jobs faster. On the other hand, sectors engaging in more trade with the rest of the world show increased job destruction rates.

To account for different productivity and relative price shocks over time, we interact proxies for the industry-specific real exchange rate with the openness indices and report the results in Table 6. While it is more difficult to disentangle the effects of trade on job flows using these new variables, the results suggest that openness and an appreciation of the real exchange rate affect job creation and job destruction disproportionately due to trade by country of origin and destination. The estimates of Table 6 show a small positive effect on increased job destruction rates for sectors trading with the rest of the world. Our data indicate that for the average sector a real depreciation within the CIS trading area is reflected by a real appreciation of relative prices towards the EU and ROW and vice versa. We, therefore, establish that sectors with more trade to CIS countries have declining job destruction rates primarily because of a depreciation of the real exchange rate within the ruble zone over the sample period. The positive effect of increased openness to the EU trading area does not disappear when the index is interacted with the real exchange rate. We take this result as evidence that increased restructuring and job reallocation are brought about by stiffer competition in EU markets. Finally, net employment growth occurs only in sectors that maintain strong trade ties in the CIS area. 


\section{Conclusions}

This paper addresses an important issue: the effects of trade liberalization on gross job flows, an area that has been relatively neglected in the trade liberalization as well as in the job flows literature. It studies the labor market of Ukraine where we view the sudden opening up of the economy to world markets as a quasi-natural experiment. We provide some evidence that 3-digit NACE sector job flows in Ukrainian manufacturing are mainly driven by idiosyncratic factors within industries. Trade is a factor of some but of minor importance in the determination of gross job flows, a finding well established in Western studies. In particular, we find that while trade with CIS decreases job destruction, trade with the EU increases excess reallocation mainly through job creation. 


\section{References}

Arrelano, M/Bover, O. (1995). Another look at the instrumental variable estimation of error-components models. Journal of Econometrics, 68, 29-51.

Aslund, A. (2002). "Why Has Ukraine Returned to Economic Growth?", Institute of Economic Research Working Paper No.15, Kiev, Ukraine.

Baldwin, J., Dunne, T. and Haltiwanger, J. (1998). "A Comparison of Job Creation and Job Destruction in Canada and the United States." The Review of Economics and Statistics, Vol. LXXX (3), pp.347-356.

Baltagi, B (1995). Econometric Analysis of panel data. John Wiley \& Sons. New York.

Bilsen, V. and Konings, J. (1998). "Job Creation, Job Destruction and Growth of Newly Established, Privatized and State-Owned Enterprises in Transition Economies: Survey Evidence from Bulgaria, Hungary and Romania." Journal of Comparative Economics, Vol. 26 (3), pp. 429-445.

Blanchard, O. (1997). The Economics of Post-Communist Transition. Claredon Lectures in Economics. Oxford.

Bond, S. (2002). "Dynamic Panel Data Models: A Guide to Micro Data Methods and Practice." Centre for Microdata Methods and Practice Working Paper CWP09/02.

Brown, D. and Earle, J. (2002a). "Gross Job Flows in Russian Industry before and after Reforms: Has Destruction Become More Creative?" Journal of Comparative Economics, Vol. 30 (1), pp. 96-133.

Brown, D. and Earle, J. (2002b). "Job Reallocation and Productivity Growth Under Alternative Economic Systems and Policies: Evidence from the Soviet Transition", IZA Discussion Paper No. 644.

Coricelli, F. and Jazbec, B. (2003). "Real Exchange Rate Dynamics in Transition Economies.” Structural Change and Economic Dynamics, Vol. 00, pp. 1-20.

Davis, S. and Haltiwanger, J. (1992). "Gross Job Creation, Gross Job Destruction and Employment Reallocation.” Quarterly Journal of Economics, Vol.107 (3), pp. 819863.

Davis, S. and Haltiwanger, J. (1999). "Gross Job Flows", in Ashenfelter, O. and D. Card. Handbook of Labor Economics, Vol. 3, Elsevier, pp.2711-2805.

Davis, S., Haltiwanger, J. and Schuh, S. (1996). Job Creation and Job Destruction, Cambridge: MIT Press.

Faggio, G. and Konings, J. (2001). "Job Creation, Job Destruction and Employment Growth in Transition Countries in the 90's", IZA Discussion Paper No. 242. 
Gourinchas, P.-O. (1999). "Exchange Rates Do Matter: French Job Reallocation and Exchange Rate Turbulence, 1984-1992”, European Economic Review, Vol. 43, pp. 1279-1316.

Greenway, D, Morgan, W. and Wright, P. (2002). Trade Liberalization and growth in developing countries. Journal of Development Economics, 67, pp. 229-244.

Hall, A.R. (2003). "Generalized Method of Moments", in Baltagi, B.H. (ed.), A companion to Theoretical Econometrics. Blakwell Publishing, pp. 230-255.

Haltiwanger, J., Lehmann, H. and Terrell, K. (2003). "Job Creation and Job Destruction in Transition Countries : Introduction to a Symposium." Economics of Transition, Vol. 11 (2), pp. 1-15

Haltiwanger, J. and Vodopivec, M. (2002). "Gross Worker and Job Flows in a Transition Economy: An Analysis of Estonia.” Labor Economics, Vol. 9 (5), pp. 601630.

Haltiwanger, J. and Vodopivec, M. (2003), "Worker Flows, Job Flows and Firm Wage Policies: An Analysis of Slovenia." Economics of Transition 11 (2), pp.253290.

Jacobsen, L., LaLonde, R. and Sullivan, D., (1993). The Costs of Worker Displacement, WE Upjohn Institute, Kalamazoo.

Klein, M.W., Schuh, S. and Triest, R.K. (2003a). "Job Creation, Job Destruction and the Real Exchange Rate", Journal of International Economics. 59, pp239-265.

Klein, M.W., Schuh, S. and Triest, R.K. (2003b). Job Creation, Job Destruction and International Competition. WE Upjohn Institute, Kalamazoo.

Konings, J., Lehmann, H. and Schaffer, M. (1996). "Employment Growth, Job Creation and Job Destruction in Polish Industry: 1988-91." Labor Economics, 3, pp.299-317.

Konings, J. Kupets, O. and Lehmann, H. (2003). "Gross Job Flows in Ukraine: Size, Ownership and Trade Effects", Economics of Transition. 11 (2), pp. 231-251.

Konings, J. and Walsh, P. (1999). "Employment Dynamics of Newly Established and Traditional Firms: A Comparison of Russia and Ukraine", LICOS Working Paper 81/1999, Centre for Transition Economics, Leuven.

Kuhn P., (2002), Losing Work, Moving On: Worker Displacement in International Perspective, W. E. Upjohn Institute for Employment Research, Kalamazoo, Michigan.

Lehmann, H., Philips, K. and Wadsworth, J. (2005). "The Incidence and Cost of Job Loss in a Transition Economy: Displaced Workers in Estonia, 1989-1999”, Journal of Comparative Economics, Vol.33 (1), pp.59-87. 
Lehmann, H., Pignatti, N. and Wadsworth, J. (2005). "The Incidence and Cost of Job Loss in the Ukrainian Labor Market, IZA Discussion Paper No. 1770, Bonn: September.

Levinsohn, J. (1999). "Employment Responses to International Liberalization in Chile", Journal of International Economics, Vol. 47 (2), pp. 321-344.

Repkine, A. and Walsh, P. (1999). "Evidence of European Trade and Investment UShaping Industrial Output in Bulgaria, Hungary, Poland and Romania", Journal of Comparative Economics, Vol.27 (4), pp.730-752. 


\section{TABLES}

Table 1. Gross Job Flows in Manufacturing

\begin{tabular}{|c|c|c|c|c|c|c|}
\hline Year & pos & neg & gross & net & exc & $\boldsymbol{N}$ \\
\hline \hline $1993-94$ & 0.009 & 0.108 & 0.118 & -0.099 & 0.019 & 7768 \\
\hline $1994-95$ & 0.016 & 0.098 & 0.114 & -0.082 & 0.033 & 8023 \\
\hline $1995-96$ & 0.019 & 0.105 & 0.123 & -0.086 & 0.037 & 7897 \\
\hline $1996-97$ & 0.018 & 0.113 & 0.132 & -0.095 & 0.037 & 8163 \\
\hline $1997-98$ & 0.022 & 0.091 & 0.113 & -0.069 & 0.045 & 7670 \\
\hline $1998-99$ & 0.030 & 0.094 & 0.124 & -0.064 & 0.060 & 9066 \\
\hline $1999-2000$ & 0.041 & 0.081 & 0.122 & -0.041 & 0.081 & 8077 \\
\hline
\end{tabular}

Table 2. Distribution of Annual Employment Growth Rates: Firm level

\begin{tabular}{|c|c|c|c|c|c|c|c|c|c|c|c|c|}
\hline Year & $1 \%$ & $5 \%$ & $10 \%$ & $25 \%$ & $50 \%$ & $75 \%$ & $90 \%$ & $95 \%$ & $99 \%$ & Mean & StDev & $\mathrm{N}$ \\
\hline \hline $93-94$ & -0.547 & -0.332 & -0.255 & -0.158 & -0.078 & -0.007 & 0.043 & 0.086 & 0.304 & -0.091 & 0.159 & 7768 \\
$94-95$ & -0.579 & -0.321 & -0.239 & -0.137 & -0.052 & 0.000 & 0.059 & 0.104 & 0.323 & -0.073 & 0.164 & 8023 \\
$95-96$ & -0.750 & -0.378 & -0.273 & -0.161 & -0.068 & 0.000 & 0.061 & 0.108 & 0.347 & -0.093 & 0.196 & 7897 \\
$96-97$ & -1.012 & -0.405 & -0.280 & -0.163 & -0.078 & -0.004 & 0.055 & 0.121 & 0.522 & -0.101 & 0.234 & 8162 \\
$97-98$ & -0.957 & -0.386 & -0.272 & -0.145 & -0.059 & 0.006 & 0.090 & 0.204 & 0.852 & -0.071 & 0.254 & 7670 \\
$98-99$ & -1.283 & -0.541 & -0.333 & -0.164 & -0.063 & 0.014 & 0.131 & 0.300 & 1.077 & -0.082 & 0.320 & 9066 \\
$99-00$ & -1.267 & -0.588 & -0.358 & -0.167 & -0.050 & 0.037 & 0.157 & 0.297 & 0.777 & -0.082 & 0.309 & 8077 \\
\hline
\end{tabular}

Table 3. Distribution of Annual Sectoral Job Creation Rates

\begin{tabular}{|c|c|c|c|c|c|c|c|c|c|c|c|}
\hline Year & $1 \%$ & $5 \%$ & $10 \%$ & $25 \%$ & $50 \%$ & $75 \%$ & $90 \%$ & $95 \%$ & $99 \%$ & Mean & StDev \\
\hline \hline $93-94$ & 0 & 0 & 0 & 0.001 & 0.004 & 0.012 & 0.030 & 0.071 & 0.226 & 0.013 & 0.029 \\
$94-95$ & 0 & 0 & 0 & 0.002 & 0.008 & 0.023 & 0.045 & 0.061 & 0.156 & 0.016 & 0.024 \\
$95-96$ & 0 & 0 & 0 & 0.003 & 0.009 & 0.024 & 0.048 & 0.087 & 0.318 & 0.023 & 0.046 \\
$96-97$ & 0 & 0 & 0 & 0.002 & 0.010 & 0.021 & 0.038 & 0.086 & 0.143 & 0.018 & 0.027 \\
$97-98$ & 0 & 0.001 & 0.002 & 0.008 & 0.018 & 0.032 & 0.045 & 0.067 & 0.104 & 0.023 & 0.020 \\
$98-99$ & 0 & 0 & 0.002 & 0.008 & 0.025 & 0.046 & 0.070 & 0.090 & 0.428 & 0.034 & 0.049 \\
$99-00$ & 0 & 0.003 & 0.011 & 0.019 & 0.033 & 0.060 & 0.090 & 0.120 & 0.219 & 0.044 & 0.038 \\
\hline
\end{tabular}

Table 4. Distribution of Annual Sectoral Job Destruction Rates

\begin{tabular}{|c|c|c|c|c|c|c|c|c|c|c|c|}
\hline Year & $1 \%$ & $5 \%$ & $10 \%$ & $25 \%$ & $50 \%$ & $75 \%$ & $90 \%$ & $95 \%$ & $99 \%$ & Mean & StDev \\
\hline \hline $93-94$ & 0 & 0.018 & 0.038 & 0.064 & 0.113 & 0.146 & 0.184 & 0.212 & 0.263 & 0.111 & 0.057 \\
$94-95$ & 0 & 0.007 & 0.017 & 0.045 & 0.085 & 0.130 & 0.193 & 0.222 & 0.405 & 0.095 & 0.071 \\
$95-96$ & 0 & 0.008 & 0.026 & 0.050 & 0.106 & 0.156 & 0.215 & 0.286 & 0.404 & 0.116 & 0.080 \\
$96-97$ & 0.011 & 0.022 & 0.033 & 0.075 & 0.114 & 0.160 & 0.196 & 0.241 & 0.369 & 0.121 & 0.067 \\
$97-98$ & 0.006 & 0.022 & 0.035 & 0.060 & 0.100 & 0.144 & 0.171 & 0.199 & 0.555 & 0.107 & 0.070 \\
$98-99$ & 0 & 0.012 & 0.017 & 0.069 & 0.111 & 0.148 & 0.212 & 0.301 & 0.433 & 0.118 & 0.080 \\
$99-00$ & 0 & 0.011 & 0.028 & 0.070 & 0.103 & 0.135 & 0.179 & 0.207 & 0.335 & 0.104 & 0.060 \\
\hline
\end{tabular}




\section{FIGURES}

Figure 1. Employment and Production in Ukrainian Industry, 1992-2000 $(1992=100)$

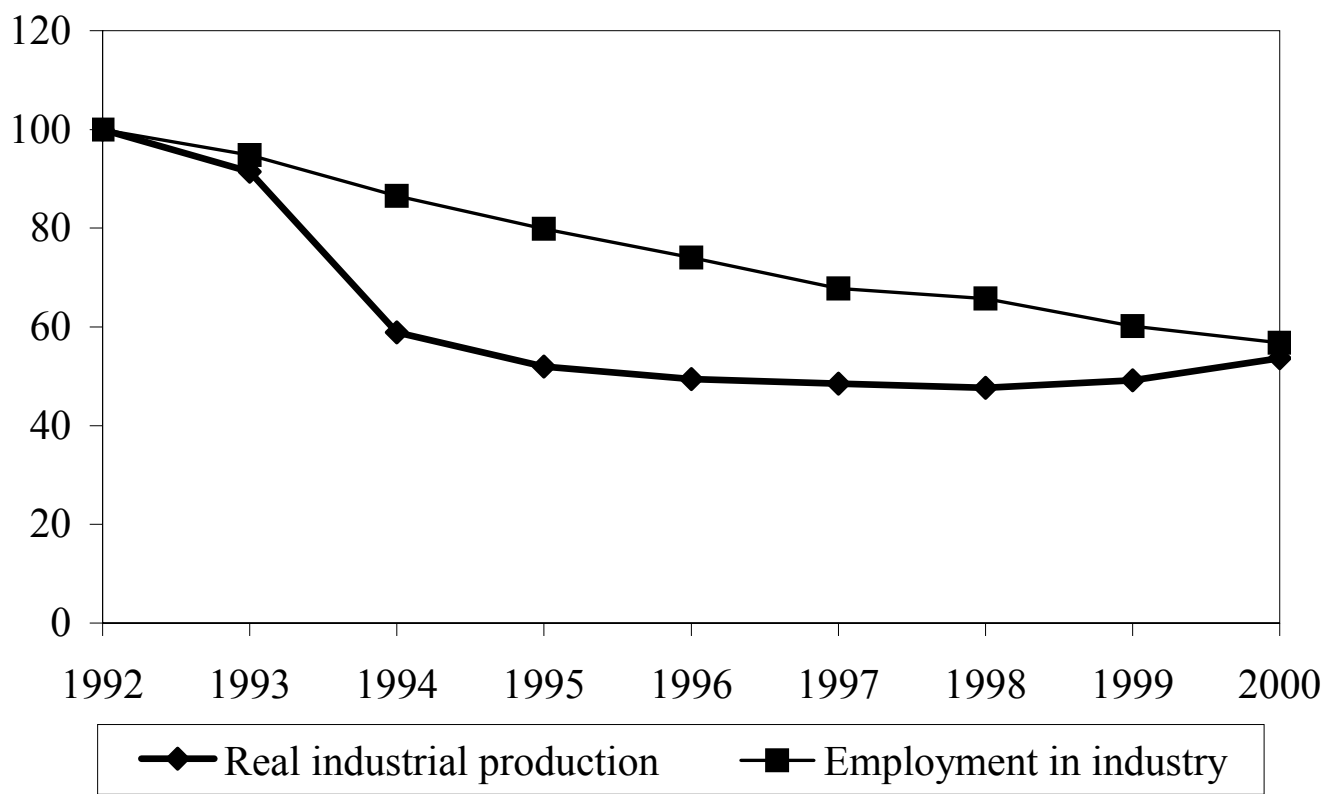

Source: Derzhkomstat, TACIS

Figure 2. Dynamics of Ukrainian Exports, 1992-2001 (1996=100)

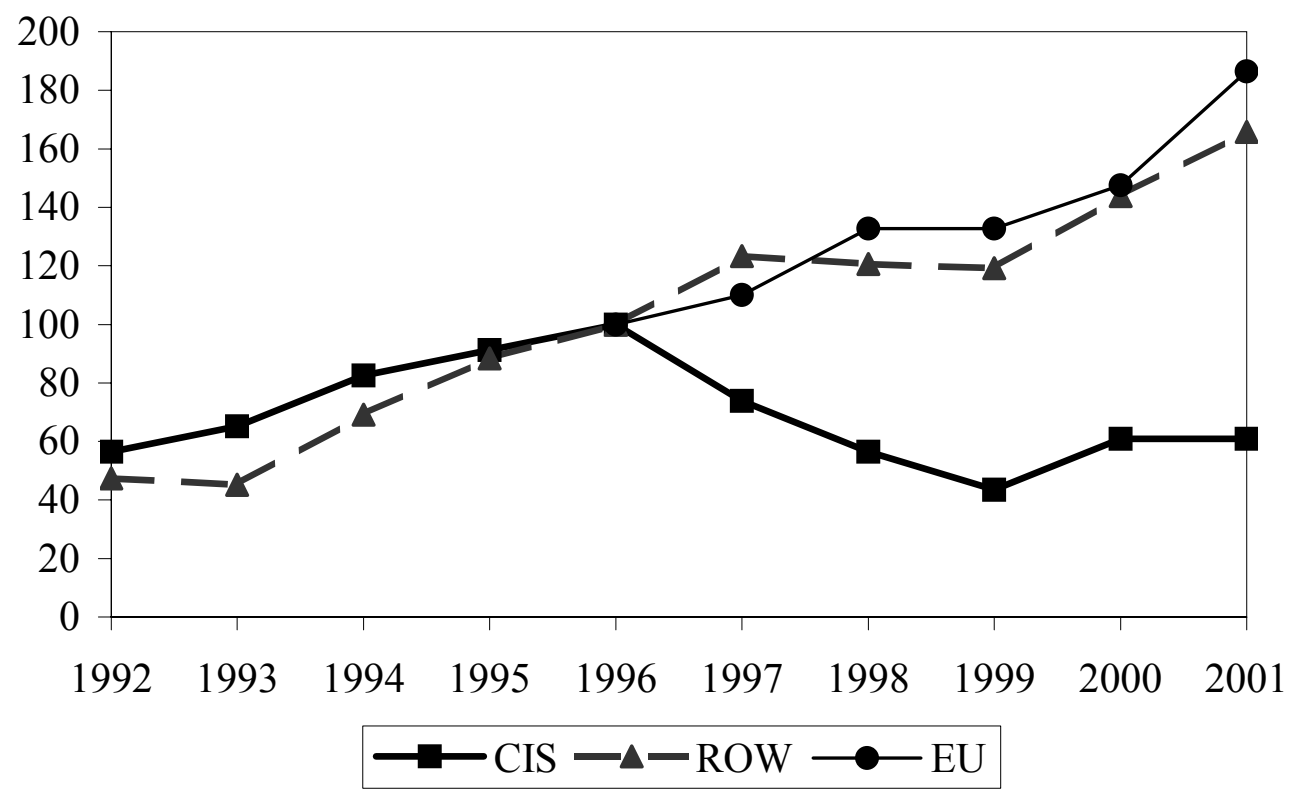

Source: Commonwealth of Independent states in 2001 (2002) 
Figure 3. Dynamics of Ukrainian Imports, 1992-2001 (1996=100)

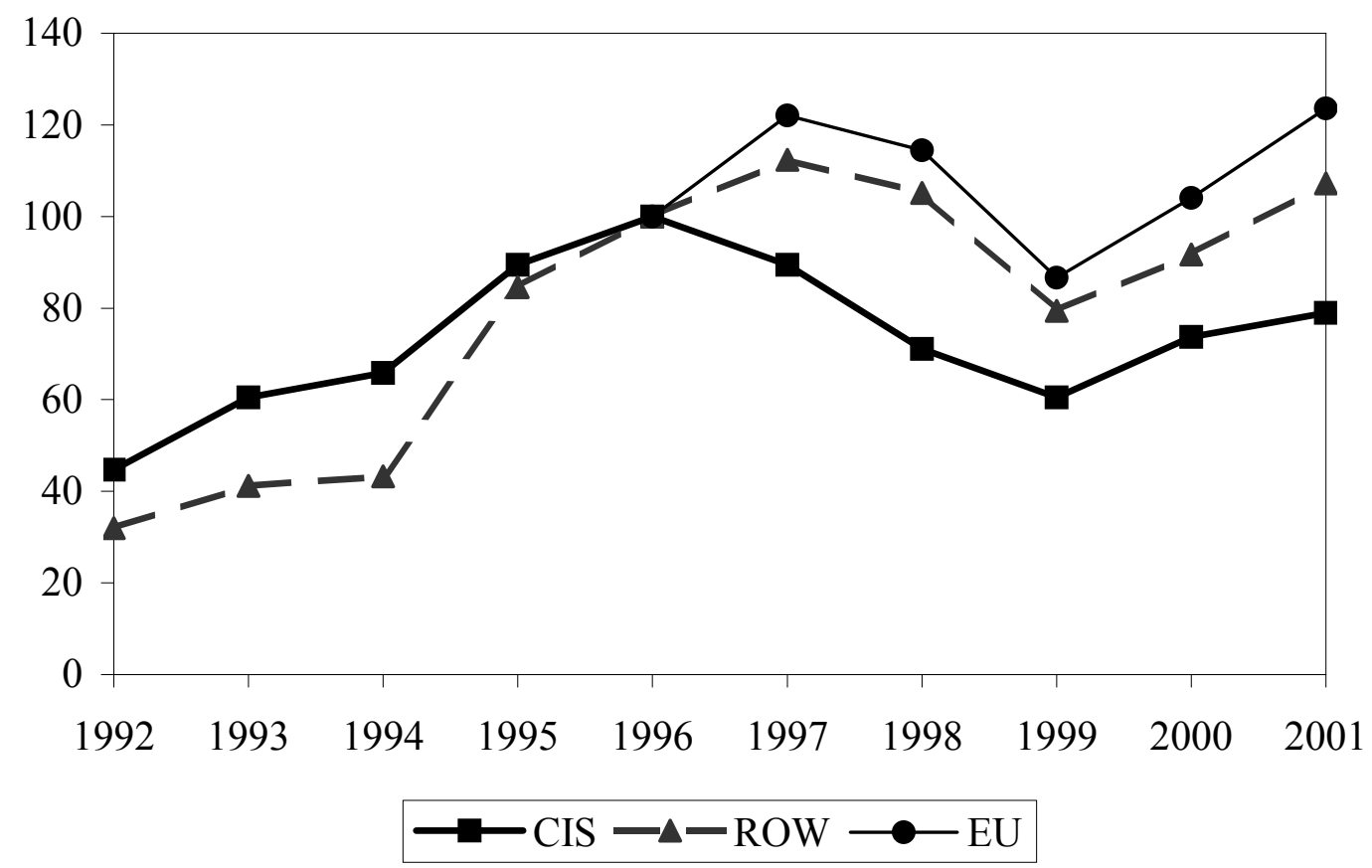

Source: Commonwealth of Independent states in 2001 (2002) 
Figure 4. Percentile distribution of openness over 3-digit sectors

A) EU countries

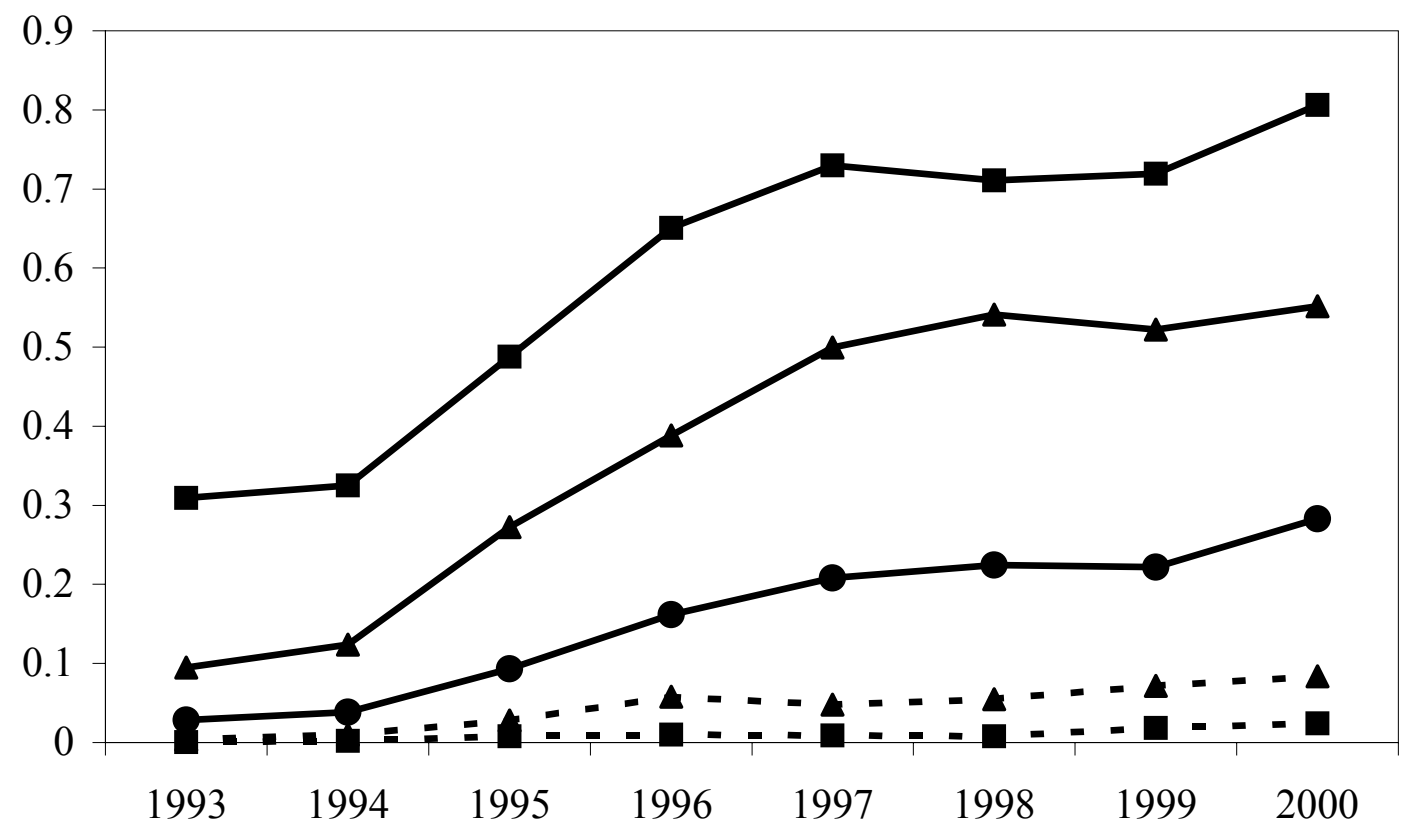

- - open_eu10 - $\boldsymbol{-}$ - open_eu25 - open_eu50

$\longrightarrow$ open_eu75 $\rightarrow$ - open_eu90

\section{B) CIS countries}

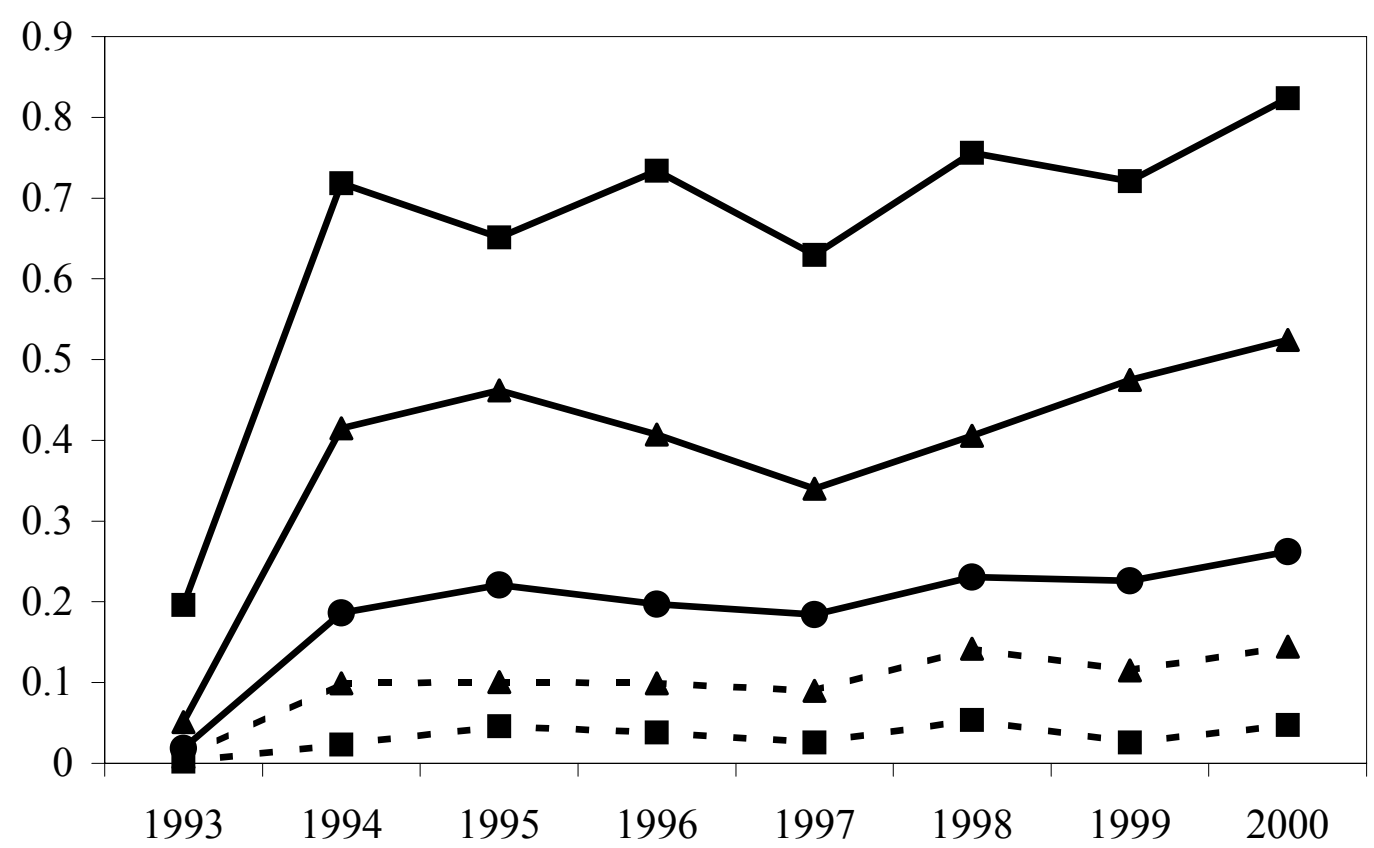

- - open_cis10 - $\boldsymbol{-}$ - open_cis25 - open_cis50 $\longrightarrow$-open_cis75 $\rightarrow$ open_cis90 
C) Rest of the World

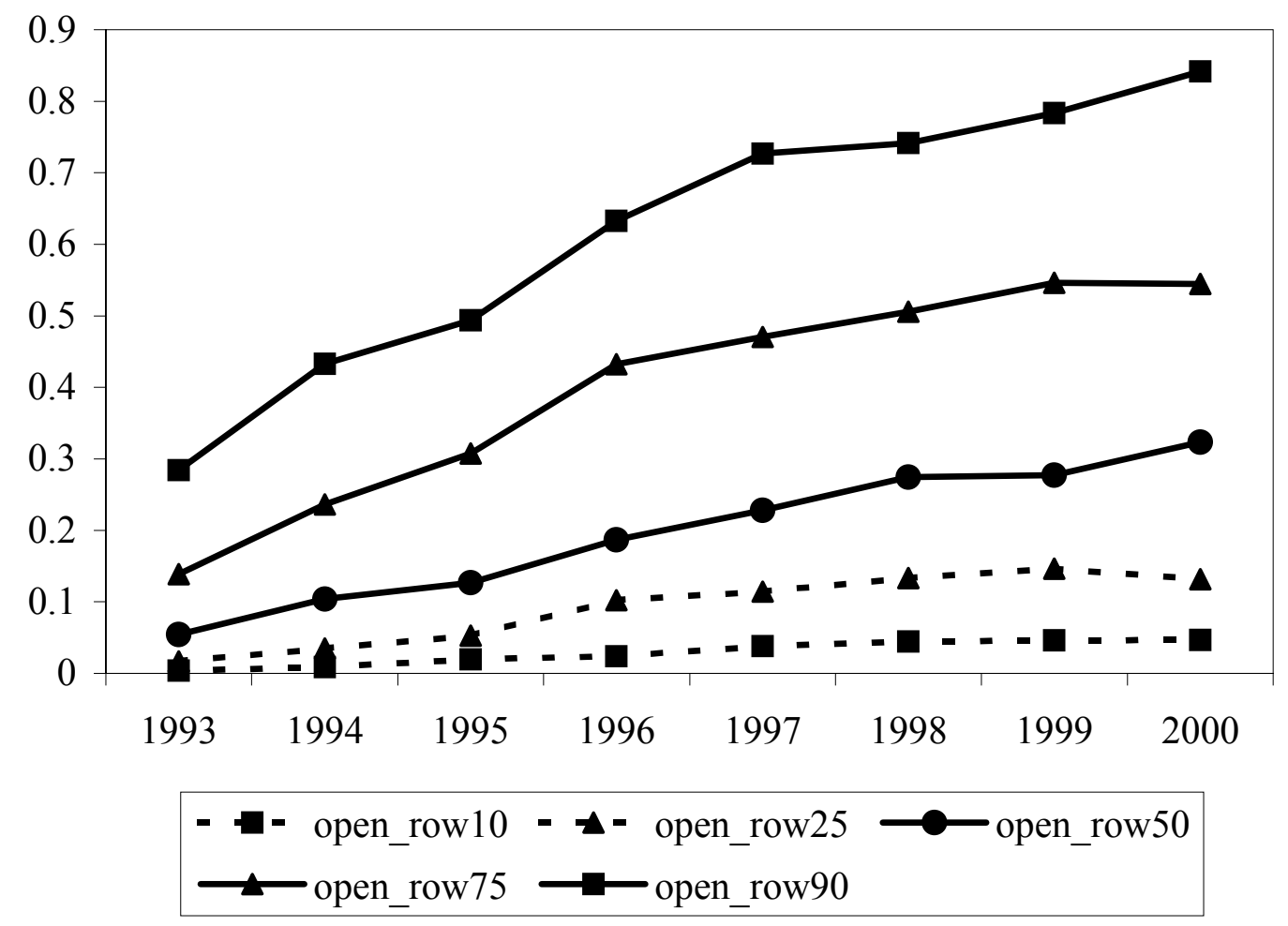

Source: authors' calculations 
Figure 5. Trade openness and sectoral job flows in three trading areas
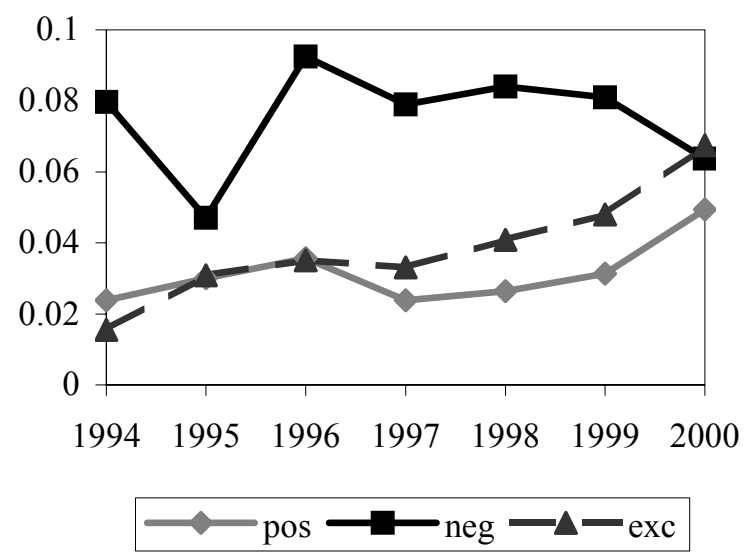

(A) EU countries - lower $25 \%$

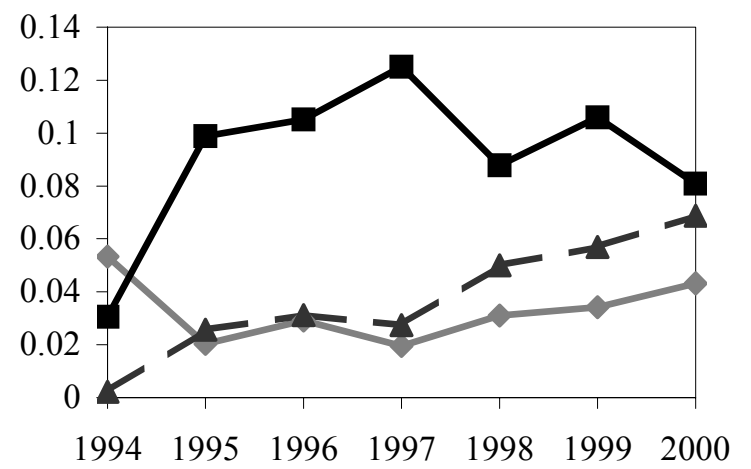

$\longrightarrow$ pos $\longrightarrow$ neg $\longrightarrow \Delta-\operatorname{exc}$

(B) CIS countries - lower $25 \%$

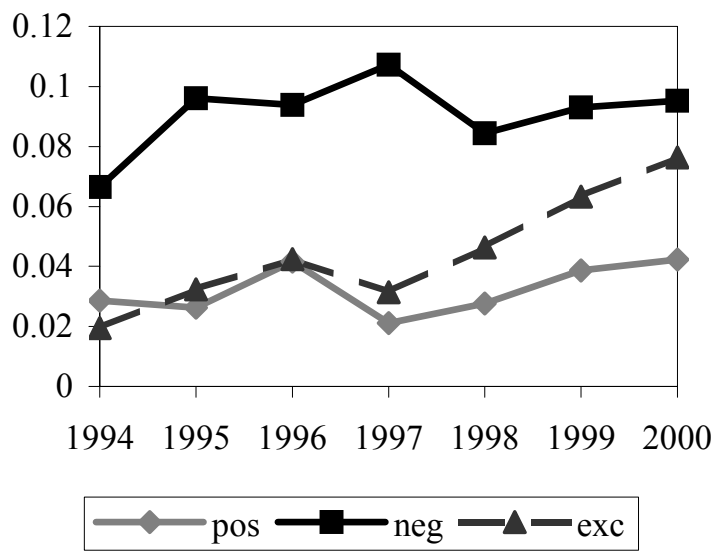

(C) ROW countries - lower $25 \%$

Source: authors' calculations.
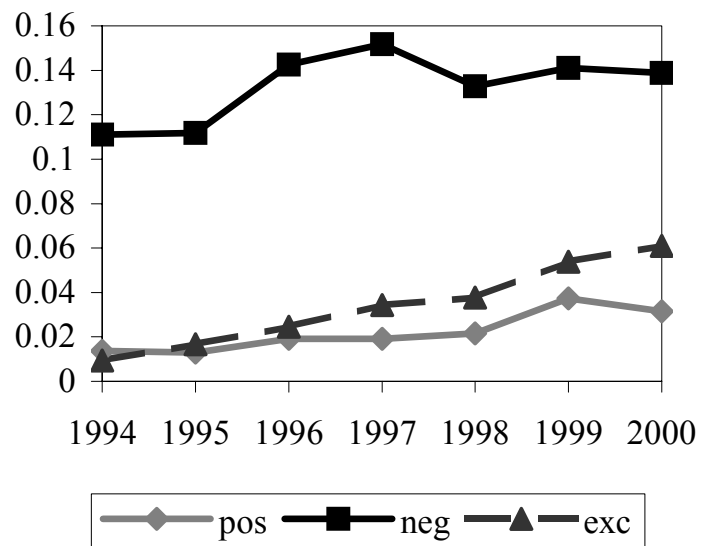

EU countries - upper $25 \%$

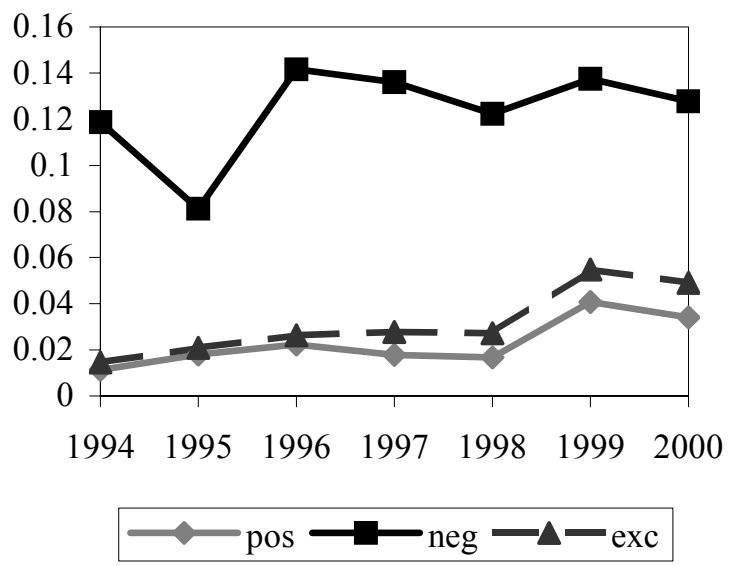

CIS countries - upper $25 \%$

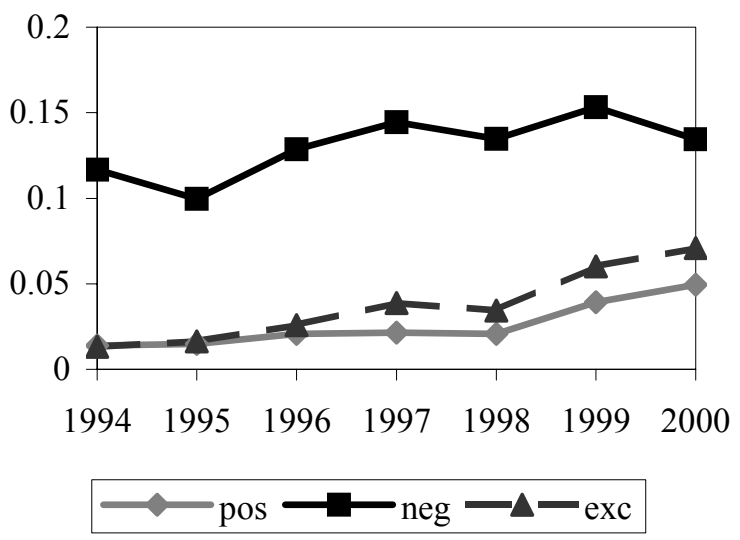

ROW countries - upper $25 \%$ 
TABLE 5

JOB FLOWS: GMM-system estimates: Dependent variable JOB CREATION, JOB DESTRUCTION, NET EMPLOYMENT GROWTH and EXCESS REALLOCATION Period 1994-2000, 576 Observations available for estimation

\begin{tabular}{|c|c|c|c|c|}
\hline $\begin{array}{l}\text { Independent } \\
\text { Variables }\end{array}$ & $\begin{array}{c}\text { JOB } \\
\text { CREATION }\end{array}$ & $\begin{array}{c}\text { JOB } \\
\text { DESTRUCTION }\end{array}$ & $\begin{array}{c}\text { NET } \\
\text { EMPLOYMENT } \\
\text { GROWTH } \\
\end{array}$ & $\begin{array}{c}\text { EXCESS } \\
\text { REALLOCATION }\end{array}$ \\
\hline$J C_{i(t-1)}$ & $\begin{array}{l}0.284 \\
(4.51) \\
\end{array}$ & $\begin{array}{l}0.048 \\
(0.77) \\
\end{array}$ & $\begin{array}{l}0.236 \\
(2.42) \\
\end{array}$ & $\begin{array}{l}0.378 \\
(5.23) \\
\end{array}$ \\
\hline $\mathbf{J D}_{\mathbf{i}(\mathrm{t}-1)}$ & $\begin{array}{l}0.119 \\
(1.28)\end{array}$ & $\begin{array}{l}0.470 \\
(8.14)\end{array}$ & $\begin{array}{l}-0.351 \\
(-2.78)\end{array}$ & $\begin{array}{l}0.168 \\
(1.94)\end{array}$ \\
\hline OI_EU & $\begin{array}{l}-0.039 \\
(-0.57)\end{array}$ & $\begin{array}{l}0.055 \\
(0.74)\end{array}$ & $\begin{array}{l}-0.094 \\
(-0.91)\end{array}$ & $\begin{array}{l}-0.091 \\
(-1.32)\end{array}$ \\
\hline OI_EU $\mathbf{U}_{\mathbf{i}(\mathrm{t}-1)}$ & $\begin{array}{l}0.066 \\
(1.69)\end{array}$ & $\begin{array}{l}-0.077 \\
(-0.93)\end{array}$ & $\begin{array}{l}0.144 \\
(1.58)\end{array}$ & $\begin{array}{l}0.079 \\
(2.06)\end{array}$ \\
\hline OI_CIS ${ }_{\text {it }}$ & $\begin{array}{l}0.031 \\
(0.35)\end{array}$ & $\begin{array}{l}0.015 \\
(0.19)\end{array}$ & $\begin{array}{l}0.016 \\
(0.11) \\
\end{array}$ & $\begin{array}{l}0.037 \\
(0.50)\end{array}$ \\
\hline OI_CIS $\mathbf{i}_{\mathbf{i}(\mathrm{t}-1)}$ & $\begin{array}{l}0.062 \\
(1.19)\end{array}$ & $\begin{array}{l}-0.078 \\
(-1.14)\end{array}$ & $\begin{array}{l}0.139 \\
(1.50)\end{array}$ & $\begin{array}{l}0.065 \\
(1.26)\end{array}$ \\
\hline OI_ROW & $\begin{array}{l}-0.005 \\
(-0.07)\end{array}$ & $\begin{array}{l}0.155 \\
(1.85)\end{array}$ & $\begin{array}{l}-0.160 \\
(-1.18)\end{array}$ & $\begin{array}{l}-0.004 \\
(-0.08)\end{array}$ \\
\hline OI_ROW & $\begin{array}{l}-0.072 \\
(-1.27)\end{array}$ & $\begin{array}{l}-0.078 \\
(-1.28)\end{array}$ & $\begin{array}{l}0.006 \\
(0.07)\end{array}$ & $\begin{array}{l}-0.087 \\
(-1.28)\end{array}$ \\
\hline$E_{i t}$ & $\begin{array}{l}0.011 \\
(0.75)\end{array}$ & $\begin{array}{l}-0.005 \\
(-0.29)\end{array}$ & $\begin{array}{l}0.015 \\
(0.56)\end{array}$ & $\begin{array}{l}0.020 \\
(1.59)\end{array}$ \\
\hline PRIV SHARE $_{i}$ & $\begin{array}{l}-0.203 \\
(-2.32)\end{array}$ & $\begin{array}{l}0.169 \\
(2.32)\end{array}$ & $\begin{array}{l}-0.373 \\
(-2.81)\end{array}$ & $\begin{array}{l}-0.106 \\
(-1.01)\end{array}$ \\
\hline Diagnostics: & & & & \\
\hline $\mathrm{MA}(1)$ & -1.822 & -4.101 & -2.591 & -2.124 \\
\hline $\operatorname{MA}(2)$ & 1.172 & 0.113 & -0.365 & 0.674 \\
\hline Sargan Test & $\begin{array}{c}82.12 \\
(77)\end{array}$ & $\begin{array}{l}79.96 \\
(77)\end{array}$ & $\begin{array}{l}82.81 \\
(77)\end{array}$ & $\begin{array}{c}83.71 \\
(77)\end{array}$ \\
\hline $\begin{array}{l}\text { Wald Test for } \\
\text { Time Dummies }\end{array}$ & $\begin{array}{c}12.25 \\
(5)\end{array}$ & $\begin{array}{c}20.83 \\
(5)\end{array}$ & $\begin{array}{c}17.89 \\
(5)\end{array}$ & $\begin{array}{c}25.96 \\
(5)\end{array}$ \\
\hline
\end{tabular}


NOTES: 1) System GMM estimates are obtained by stacking (T-2) equations in first differences and in levels corresponding to periods $3, \ldots, \mathrm{T}$. We then use lagged differences of the variables as instruments in levels (dated t-1, etc.) in addition to the instruments specified for the difference equations. See Blundell and Bond (1998)

2) The t-statistic, reported in the parentheses below the point estimates, is corrected and robust to heteroskedasticity over industries and time. A Constant and Time dummies are always included but not reported; the Wald test for the joint significance of those variables is reported in the last row of the table; it is a chi-square test under the null of no significance (degrees of freedom are in parenthesis). MA(1) (and MA(2)) is a test of first-order (and second-order) serial correlation, based on the standardized first-difference residual autocovariances asymptotically distributed as $\mathrm{N}(0,1)$ under the null of no autocorrelation. Sargan's test is a test of over-identifying restrictions, which is a chi-square under the null of no significance or instrument validity (degrees of freedom (number of restriction) given in parenthesis). 
TABLE 6

JOB FLOWS: GMM-system estimates: Dependent variable JOB CREATION, JOB DESTRUCTION, NET EMPLOYMENT GROWTH and EXCESS REALLOCATION

Period 1994-2000, 588 Observations available for estimation

\begin{tabular}{|c|c|c|c|c|}
\hline $\begin{array}{l}\text { Independent } \\
\text { Variables }\end{array}$ & $\begin{array}{c}\text { JOB } \\
\text { CREATION }\end{array}$ & $\begin{array}{c}\text { JOB } \\
\text { DESTRUCTION }\end{array}$ & $\begin{array}{c}\text { NET } \\
\text { EMPLOYMENT } \\
\text { GROWTH } \\
\end{array}$ & $\begin{array}{c}\text { EXCESS } \\
\text { REALLOCATION }\end{array}$ \\
\hline$J C_{i(t-1)}$ & $\begin{array}{l}0.258 \\
(2.75) \\
\end{array}$ & $\begin{array}{l}-0.020 \\
(-0.21) \\
\end{array}$ & $\begin{array}{l}0.278 \\
(1.86) \\
\end{array}$ & $\begin{array}{l}0.279 \\
(3.93) \\
\end{array}$ \\
\hline$J D_{i(t-1)}$ & $\begin{array}{l}0.076 \\
(1.09)\end{array}$ & $\begin{array}{l}0.469 \\
(9.18)\end{array}$ & $\begin{array}{l}-0.393 \\
(-4.30)\end{array}$ & $\begin{array}{l}0.152 \\
(2.25)\end{array}$ \\
\hline OI_EU $\mathbf{U}_{\mathrm{it}} * \mathrm{E}_{\mathrm{it}}$ & $\begin{array}{l}-0.011 \\
(-1.08) \\
\end{array}$ & $\begin{array}{l}0.012 \\
(0.91) \\
\end{array}$ & $\begin{array}{l}-0.023 \\
(-1.36) \\
\end{array}$ & $\begin{array}{l}-0.014 \\
(-1.55)\end{array}$ \\
\hline OI_EU $\mathbf{U}_{\mathbf{i}(\mathrm{t}-1)} * \mathbf{E}_{\mathbf{i}(\mathrm{t}-1)}$ & $\begin{array}{l}0.013 \\
(1.38) \\
\end{array}$ & $\begin{array}{l}-0.011 \\
(-0.81) \\
\end{array}$ & $\begin{array}{l}0.025 \\
(1.43) \\
\end{array}$ & $\begin{array}{l}0.019 \\
(2.17)\end{array}$ \\
\hline OI_CIS ${ }_{i t} * E_{i t}$ & $\begin{array}{l}0.015 \\
(0.95) \\
\end{array}$ & $\begin{array}{l}-0.046 \\
(-2.74) \\
\end{array}$ & $\begin{array}{l}0.061 \\
(2.20)\end{array}$ & $\begin{array}{l}0.025 \\
(1.72) \\
\end{array}$ \\
\hline OI_CIS ${ }_{i(t-1)} * E_{i(t-1)}$ & $\begin{array}{l}-0.003 \\
(-0.42)\end{array}$ & $\begin{array}{l}0.032 \\
(1.98)\end{array}$ & $\begin{array}{l}-0.035 \\
(-1.67)\end{array}$ & $\begin{array}{l}-0.016 \\
(-1.33)\end{array}$ \\
\hline OI_ROW ${ }_{i t} * E_{i t}$ & $\begin{array}{l}0.005 \\
(0.46)\end{array}$ & $\begin{array}{l}0.024 \\
(1.88) \\
\end{array}$ & $\begin{array}{l}-0.018 \\
(-0.99) \\
\end{array}$ & $\begin{array}{l}-0.000 \\
(-0.03) \\
\end{array}$ \\
\hline OI_ROW $W_{\mathrm{i}(\mathrm{t}-1)} * \mathbf{E}_{\mathrm{i}(\mathrm{t}-1)}$ & $\begin{array}{l}-0.010 \\
(-0.43) \\
\end{array}$ & $\begin{array}{l}-0.022 \\
(-1.96) \\
\end{array}$ & $\begin{array}{l}0.019 \\
(1.21) \\
\end{array}$ & $\begin{array}{l}-0.002 \\
(0.19) \\
\end{array}$ \\
\hline PRIV SHARE $_{i}$ & $\begin{array}{l}-0.104 \\
(-1.89) \\
\end{array}$ & $\begin{array}{l}0.084 \\
(1.78) \\
\end{array}$ & $\begin{array}{l}-0.189 \\
(-2.36) \\
\end{array}$ & $\begin{array}{l}-0.075 \\
(-1.73) \\
\end{array}$ \\
\hline Diagnostics: & & & & \\
\hline $\operatorname{MA}(1)$ & -1.947 & -4.060 & -2.518 & -2.255 \\
\hline $\mathrm{MA}(2)$ & 1.078 & 0.740 & -0.316 & 0.704 \\
\hline Sargan Test & $\begin{array}{c}90.13 \\
(95) \\
\end{array}$ & $\begin{array}{l}87.55 \\
(95) \\
\end{array}$ & $\begin{array}{c}86.58 \\
(95) \\
\end{array}$ & $\begin{array}{l}91.87 \\
(95) \\
\end{array}$ \\
\hline $\begin{array}{l}\text { Wald Test for Time } \\
\text { Dummies }\end{array}$ & $\begin{array}{c}19.10 \\
(5)\end{array}$ & $\begin{array}{c}15.59 \\
(5)\end{array}$ & $\begin{array}{c}22.60 \\
(5)\end{array}$ & $\begin{array}{c}25.17 \\
(5)\end{array}$ \\
\hline
\end{tabular}

NOTES:

1) See 1) and 2) of Table 5. 
APPENDIX 1

Definitions of variables used in estimation

\begin{tabular}{|c|c|c|c|}
\hline Variable & Description & Definition & Source \\
\hline $\mathrm{JC}_{\mathrm{it}}$ & $\begin{array}{l}\text { Job creation rate in } \\
\text { industry } i \text { in year } t\end{array}$ & $\begin{array}{l}\frac{\sum_{\mathrm{p} \in \mathrm{M}^{+}} \Delta \mathrm{Emp}_{\mathrm{pit}}}{1 / 2\left(\mathrm{Emp}_{\mathrm{it}}+\mathrm{Emp}_{\mathrm{i}(\mathrm{t}-1)}\right)}, \\
\text { where } \mathrm{M}^{+}=\left\{\mathrm{p} \mid \Delta \mathrm{Emp}_{\mathrm{pit}}>0\right\}\end{array}$ & $\begin{array}{l}\text { Derzhkomstat registry } \\
\text { of industrial } \\
\text { enterprises, 1993- } \\
2000\end{array}$ \\
\hline$J_{\text {it }}$ & $\begin{array}{l}\text { Job destruction rate } \\
\text { in industry } i \text { in year } t\end{array}$ & $\begin{array}{l}\frac{\sum_{\mathrm{p} \in \mathrm{M}^{-}}\left|\Delta \mathrm{Emp}_{\mathrm{pit}}\right|}{1 / 2\left(\mathrm{Emp}_{\mathrm{it}}+\mathrm{Emp}_{\mathrm{i}(\mathrm{t}-1)}\right)}, \\
\text { where } \mathrm{M}^{-}=\left\{\mathrm{p} \mid \Delta \mathrm{Emp}_{\mathrm{pit}}<0\right\}\end{array}$ & $\begin{array}{l}\text { Derzhkomstat registry } \\
\text { of industrial } \\
\text { enterprises, 1993- } \\
2000\end{array}$ \\
\hline $\mathrm{JF}_{\mathrm{it}}$ & $\begin{array}{l}\text { Job flow rates in } \\
\text { industry } i \text { in year } t\end{array}$ & $\left\{\mathrm{JC}_{\mathrm{it}}, \mathrm{JD}_{\mathrm{it}}, \mathrm{JR}_{\mathrm{it}}, \mathrm{JN}_{\mathrm{it}}, \mathrm{JE}_{\mathrm{it}}\right\}$ & $\begin{array}{l}\text { Derzhkomstat registry } \\
\text { of industrial } \\
\text { enterprises, 1993- } \\
2000\end{array}$ \\
\hline OI_EU ${ }_{\text {it }}$ & $\begin{array}{l}\text { Openness index with } \\
\text { EU countries in } \\
\text { industry } i \text { in year } t\end{array}$ & $\begin{array}{l}\quad \frac{E x p \_E U_{i t}+I m p \_E U_{i t}}{\text { Exp_EU }_{\text {it }}+\mathrm{Imp}_{-} \mathrm{EU}_{\mathrm{it}}+\operatorname{Prod}_{\mathrm{it}}} \\
\text { where Exp_EU denotes exports } \\
\text { to EU countries (nominal USD), } \\
\text { Imp_EU denotes imports from } \\
\text { EU countries (nominal USD), } \\
\text { and Prod denotes sectoral } \\
\text { production in nominal USD } \\
\text { (converted from UHA using } \\
\text { official average annual exchange } \\
\text { rate) }\end{array}$ & $\begin{array}{l}\text { Derzhkomstat registry } \\
\text { of industrial } \\
\text { enterprises for } \\
\text { production, Ukrainian } \\
\text { Customs Committee } \\
\text { data on import and } \\
\text { export volumes by } \\
\text { countries of origin } \\
\text { and destination }\end{array}$ \\
\hline $\mathrm{OI}_{-} \mathrm{CIS}$ it & $\begin{array}{l}\text { Openness index with } \\
\text { CIS countries in } \\
\text { industry } i \text { in year } t\end{array}$ & $\begin{array}{l}\frac{\text { Exp_CIS }_{\mathrm{it}}+\mathrm{Imp}_{-} \mathrm{CIS}_{\mathrm{it}}}{\text { Exp_CIS }_{\mathrm{it}}+\mathrm{Imp}_{-} \mathrm{CIS}_{\mathrm{it}}+\text { Prod }_{\mathrm{it}}} \\
\text { where Exp_CIS denotes exports } \\
\text { to CIS countries (nominal USD), } \\
\text { Imp_CIS denotes imports from } \\
\text { CIS countries (nominal USD), } \\
\text { and Prod denotes sectoral } \\
\text { production in nominal USD } \\
\text { (converted from UHA using } \\
\text { official average annual exchange } \\
\text { rate) }\end{array}$ & $\begin{array}{l}\text { Derzhkomstat registry } \\
\text { of industrial } \\
\text { enterprises for } \\
\text { production, Ukrainian } \\
\text { Customs Committee } \\
\text { data on import and } \\
\text { export volumes by } \\
\text { countries of origin } \\
\text { and destination }\end{array}$ \\
\hline OI_ROW & $\begin{array}{l}\text { Openness index with } \\
\text { countries from the } \\
\text { rest of the world in } \\
\text { industry } i \text { in year } t\end{array}$ & $\begin{array}{l}\frac{\text { Exp_ROW }_{\text {it }}+\mathrm{Imp}_{-} \mathrm{ROW}_{\mathrm{it}}}{\text { Exp_ROW }_{\mathrm{it}}+\mathrm{Imp}_{-} \mathrm{ROW}_{\mathrm{it}}+\operatorname{Pr}} \\
\text { where Exp_ROW denotes } \\
\text { exports to ROW countries } \\
\text { (nominal USD), } \\
\text { Imp_ROW denotes imports from }\end{array}$ & $\begin{array}{l}\text { Derzhkomstat registry } \\
\text { of industrial } \\
\text { enterprises for } \\
\text { production, Ukrainian } \\
\text { Customs Committee } \\
\text { data on import and }\end{array}$ \\
\hline
\end{tabular}




\begin{tabular}{|c|c|c|c|}
\hline & & $\begin{array}{l}\text { ROW countries (nominal USD), } \\
\text { and Prod denotes sectoral } \\
\text { production in nominal USD } \\
\text { (converted from UHA using } \\
\text { official average annual exchange } \\
\text { rate) }\end{array}$ & $\begin{array}{l}\text { export volumes by } \\
\text { countries of origin } \\
\text { and destination }\end{array}$ \\
\hline $\mathrm{E}_{\mathrm{it}}$ & $\begin{array}{l}\text { Multilateral real } \\
\text { exchange rate }\end{array}$ & $\begin{array}{l}\sum_{\mathrm{j}=1}^{3} \mathrm{w}_{\mathrm{ij}(\mathrm{t}-1)} \mathrm{E}_{\mathrm{jt}} \text {, where } \mathrm{j} \text { indexes } 3 \\
\text { trading areas (EU, CIS, ROW), } \\
\text { Ejt denotes bilateral real } \\
\text { exchange rate (UHA to Euro, } \\
\text { Russian Ruble and USD } \\
\text { correspondingly) defined as } \\
\left.\text { [ln(nominal exchange rate }{ }_{\mathrm{jt}}\right) \\
\left.\left.+\ln \left(\mathrm{ukrppi}_{\mathrm{t}}\right)-\ln \left(\mathrm{ppi}_{\mathrm{j} t}\right)\right] \text {, and } \mathrm{w}_{\mathrm{ij}(\mathrm{t}-1)}\right) \\
\text { denotes industry-specific trade } \\
\text { share weights in the previous } \\
\text { year }\end{array}$ & $\begin{array}{l}\text { National Bank of } \\
\text { Ukraine } \\
\text { (http://www.bank.gov } \\
\text {.ua) for the official } \\
\text { exchange rates, } \\
\text { OECD Economic } \\
\text { Trends for PPI in EU } \\
\text { countries, Russia in } \\
\text { Figures for PPI in } \\
\text { Russia, Ukrainian } \\
\text { Economic Trends for } \\
\text { PPI in Ukraine, BLS } \\
\text { data base for US PPI }\end{array}$ \\
\hline Privshare $_{i}$ & $\begin{array}{l}\text { Share of non-state } \\
\text { firms in sector } i \text { in } \\
2000\end{array}$ & & $\begin{array}{l}\text { Derzhkomstat firm- } \\
\text { level data on } \\
\text { ownership in } 2000\end{array}$ \\
\hline
\end{tabular}


APPENDIX 2

Institutional Changes and Trade Regime

Institutional changes in international trade regime in Ukraine

\begin{tabular}{|c|c|}
\hline Time & Event \\
\hline $\begin{array}{l}\text { November } \\
1994\end{array}$ & $\begin{array}{l}\text { The system of export quotas and licenses, which had covered } 40 \% \text { of } \\
\text { exports, was narrowed to include only grain, ferrous and nonferrous scrap, } \\
\text { cast iron, and coal, in addition to goods subject to voluntary export restraint } \\
\text { or other international agreements. } \\
\text { A new system of export contract pre-registration was adopted; } 20 \text { categories } \\
\text { of goods were originally subject to the registration requirement, in addition } \\
\text { to all goods traded under barter arrangements }\end{array}$ \\
\hline $\begin{array}{l}\text { December } \\
1994\end{array}$ & The state orders and contracts systems for foreign trade were eliminated \\
\hline January 1995 & $\begin{array}{l}\text { Export quotas and licenses on all above products except grain were } \\
\text { eliminated }\end{array}$ \\
\hline March 1995 & $\begin{array}{l}\text { The scope of export contract pre-registration was limited to goods subject to } \\
\text { the special export regime, voluntary export restraint, and actual or potential } \\
\text { antidumping actions. } \\
\text { A system of minimum indicative prices for a range of export products } \\
\text { covering one-half of total exports was instituted }\end{array}$ \\
\hline $\begin{array}{l}\text { December } \\
1995\end{array}$ & $\begin{array}{l}\text { Indicative export prices were removed for all good except for goods subject } \\
\text { to actual and prospective antidumping actions and voluntary export } \\
\text { restraints. }\end{array}$ \\
\hline January 1996 & $\begin{array}{l}\text { Licensing requirement for grain exports was abolished. } \\
\text { Import tariffs on many agricultural goods were raised to } 30 \% \text {. }\end{array}$ \\
\hline $\begin{array}{l}\text { April-May } \\
1996\end{array}$ & $\begin{array}{l}\text { Export taxes, once fully eliminated, were reapplied to animals and skins in } \\
\text { April } 1996 \text { and to ferrous and nonferrous metals and scrap in May } 1996\end{array}$ \\
\hline June 1996 & $\begin{array}{l}\text { Import duties of about } 15 \% \text { on coal and refined petroleum products were } \\
\text { introduced. Specific or mixed ad-valorem /specific tariffs have been } \\
\text { introduced for numerous food products, motor vehicles, tires, textiles and } \\
\text { clothing, alcohol, tobacco, furs, and radio equipment. }\end{array}$ \\
\hline June 1997 & Export surrender requirement was revoked \\
\hline March 1998 & Limits on auto imports were imposed \\
\hline $\begin{array}{l}\text { September } \\
1998\end{array}$ & $\begin{array}{l}\text { Foreign exchange restrictions were re-introduced. } \\
\text { Limits were imposed on the making of advance import payments. } \\
\text { A 50\% surrender requirement was introduced. }\end{array}$ \\
\hline July 1999 & $\begin{array}{l}\text { A uniform, nondiscriminatory import surcharge of } 2 \% \text { was introduced. } \\
\text { The restriction on advance import payments was eliminated. }\end{array}$ \\
\hline $\begin{array}{l}\text { September } \\
1999\end{array}$ & An export duty on sunflower seeds was introduced. \\
\hline January 2000 & $\begin{array}{l}\text { A uniform, nondiscriminatory import surcharge of } 2 \% \text { was eliminated. } \\
\text { The number of excisable imported goods has decreased from } 20 \text { to } 5 \\
\text { categories (alcohol, tobacco, oil products, automobiles, jewelry). }\end{array}$ \\
\hline
\end{tabular}

Sources: EBRD Transition Report 2002, IMF annual report on exchange arrangements and exchange restrictions (several issues) 